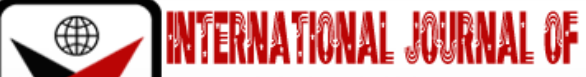

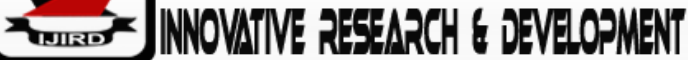

ISSN 2278-0211 (Online)

\section{Mathematics Teaching Anxiety among College of Education Pre-service Teachers in Ghana: The Influence of Mathematics Achievement and Field Experiences}

Isaac Bengre Taley
Tutor, Department of Mathematics \& ICT, Mampong Technical College of Education, Ghana
Opoku Adusei
Tutor, Department of Education, Mampong Technical College of Education, Ghana
Douglas Ndamenenu Koranteng
Tutor, Department of Mathematics \& ICT, Mampong Technical College of Education, Ghana

\begin{abstract}
:
This study sought to explore the influence of mathematics achievement and field experience on pre-service teachers' anxiety towards the teaching of mathematics. Data was conveniently gathered from 119 pre-service mathematics teachers in a college of education in Ghana. The pre-service teachers were in two groups of mathematics major and mathematics minor. Using the English version of the Mathematics Teaching Anxiety Scale, we observed that the preservice teachers' anxiety towards mathematics teaching was generally moderate. Additionally, we observed that the pre-service teachers' mathematics teaching anxiety was related to their content knowledge, self-efficacy, teaching processes, and assessment practices. Our analysis further revealed that the major and minor pre-service mathematics teachers were different in their mathematics teaching anxiety regarding their self-efficacy but indifferent in the other three models. More so, we observed that the effect of mathematics achievement and field experience was statistically significant in the pre-service teachers' mathematics teaching anxiety regarding content knowledge. Nevertheless, mathematics achievement was the major predictor. Despite of the prevalence of mathematics teaching anxiety among the pre-service teachers, we are of the view that additional field experiences and subsequent mathematics pedagogic courses may help reduce the anxiety levels.
\end{abstract}

Keywords: Mathematics teaching anxiety; mathematics achievement; field experience; pre-service mathematics teacher

\section{Introduction}

Colleges of education in Ghana train teachers to primarily teach at the basic schools. Since 2018/2019 academic year, colleges of education started to implement a new curriculum that will lead to the award of a bachelor's degree in basic education to pre-service teachers(Institute of Education [IoE], 2018; Institute for teacher education and continuing professional development, [ITECPD], 2018). To this end, colleges of education have been accredited to provide specialism training to pre-service teachers to pursue specialism programmes in three main domains vice-a-vice early childhood, primary, and junior high school (JHS) specialisms. The JHS specialism programme (like the other specialisms) provides an opportunity for pre-service teachers to specialize in one subject area known as the major and to also have a minor subject of specialization. By this arrangement, pre-service teachers upon successful completion of the course of study are obliged to teach primarily in their major and/or minor area(s) of specialization. The pre-service teacher education curriculum has been structured to equip pre-service teachers with enriched technological and pedagogical content knowledge. This degree-teacher training programme comes in two models - classroom instruction and field experiences. During classroom instruction, pre-service teachers receive tuition in content, technology, and pedagogy courses from teacher educators. The field experience component includes school-based observational experience and teaching practicum. In one of these colleges of education where the lens of this study was focused, observational field experience and taught courses have been fused on their teaching time table and field experience assigned six hours a week though it is a three-credit hour course.

By the end of the fifth semester of the implementation of this degree programme, pre-service teachers majoring and/or minoring in mathematics within the JHS specialism have completed courses related to content knowledge, pedagogical course, school experience, and teaching practicum. Through these courses,pre-service teachers have been taught how to differently and effectively teach mathematics and also the use of manipulative materials in the teaching of specific mathematical contents. With these preparatory arrangements, it could be hazarded that pre-service mathematics teachers are psychologically and emotionally prepared to take up teaching roles in the coming years. Nonetheless, one 
phenomenon that could gird pre-service mathematics teachers' ability to effectively teach mathematics at the basic school is their level of self-confidence which is born out of anxiety to teach. Studies (Deringol, 2018; Haciomeroglu, 2014; Levine, 1993; Murat Peker et al., 2010)have shown that anxiety towards the teaching of mathematics is analogous with preservice teachers, and this according to research(Brown, Westenskow, \& Moyer-Packenham, 2012; Çenberci, 2019; Peker\& Ertekin, 2011; Peker et al., 2010)affect their teaching as well.

The concept of mathematics teaching anxiety explains a teachers' feeling of tension, apprehension, and fretfulness manifested with activities relating to mathematics teaching(Akinsola, 2014; Gardner \& Leak, 1994; Peker, 2006).Gardner and Leak, (1994)however added that the phenomenon can be revealed at the preparation as well as the execution phases of the teaching process. The subject of mathematics teaching anxiety is important as it has a dire influence on pre-service teachers' potential in enacting effective teaching of mathematics (Brown et al., 2012; Çenberci, 2019; Peker \& Ertekin, 2011; Murat Peker et al., 2010)and students' learning of mathematics (Akinsola, 2014; Peker et al., 2010).

Though there may be unlimited causes to pre-service teachers' anxiety in teaching mathematics, Akinsola (2014)emphasized the perceived difficulty with teaching, inadequate teaching competencies in teaching mathematics concepts, inadequate interest in the teaching profession, and inability to modify ones' teaching concerning learners' developmental stages. Similarly, the lack of internship for pre-service teachers, lack of self-confidence needed for preservice teachers to try new methods, and the insufficiency of mathematical content knowledge pre-service teachers need to meet curriculum requirements could contribute to pre-service teachers' anxiety to teach mathematics(Hoşşirin, 2010 as cited in Deringol, 2018, p. 93). Nonetheless,Peker (2006) and Levine (1993) also identified inadequate mathematics content knowledge, insufficient teaching skills, insufficient teaching practicum, attitude towards mathematics, and low self-confidence. Broadly speaking, however, Gardner and Leak (1994) confined the sources of teaching anxiety to include the activities which directly affect classroom learning and will require teaching skills and abilities to deal with. These activities include answering students' questions; attending to group discussions; class control and monitoring(Gardner \& Leak, 1994).

Research has shown that mathematics teaching anxiety among pre-service teachers also presents itself in different spheres of the teaching endeavour. For example, Peker (2006) and Baspinar and Peker (2016) identified four spheres of mathematics teaching anxiety relating to content knowledge, self-confidence, attitude towards mathematics teaching, and teaching/pedagogical content knowledge. Haciomeroglu (2014)however identified three spheres of mathematics teaching anxiety relating self-confidence, attitude towards mathematics teaching, and teaching knowledge. Elsewhere, Hunt and Sari (2019) deduced two constructs, that is self-directed mathematics teaching anxiety which related to teachers' teaching practice and perceived ability, and the second been pupil/student-directed mathematics teaching anxiety which also related to teachers' anxiety concerning pupils/students failing assessments or not reaching curriculum/school targets. Alkan, Coşguner, and Fidan (2019) however found mathematics teaching anxiety to be a single construct.

Relating to some of these constructs of mathematics teaching anxiety of pre-service teachers, Aksu and Kul (2019),Peker(2015), and Ural (2015) observed a reverse relationship between self-efficacy and mathematics teaching anxiety among pre-service teachers. The analogy according to Korkmaz (2004) was that a high level of self-efficacy led teachers to explore more creative teaching methods and also improved their performance which could then enhance students' mathematics learning. Similarly, Aksu and Kul (2019)hypothesized that the execution of correct and effective teaching of mathematics by pre-service teachers is anchored in their self-efficacy. On the construct relating to attitudes towards teaching and learning of mathematics,Baspinar and Peker (2016) observed a negative relationship between preservice teachers' mathematics teaching anxiety and attitudes towards the teaching of mathematics. In a triatic relationship among attitude, beliefs, and mathematics teaching anxiety, Haciömeroğlu (2013) held the view that beliefsaffectedattitude. And since mathematics beliefs related to mathematics teaching anxiety negatively (Ertekin, 2010), it suffices to admit the negative association between pre-service teachers' mathematics teaching anxietiesand their attitudes toward the teaching of mathematics.

Another important construct running through the literature on pre-service teachers' mathematics teaching anxiety is the pre-service teachers' pedagogical content knowledge which significantly affects the quality of teaching (Bostan \& Osmanoğlu, 2016).In explaining a teacher's pedagogical knowledge, Aksu and Kul (2019) stressed the thought that it encapsulates a teacher's special knowledge of content and subject matter, curriculum resources, instructional procedures and learning objectives. Both mathematics content and teaching knowledge were found to be negatively related to pre-service mathematics teachers anxiety towards the teaching of mathematics (Baspinar \& Peker, 2016). In particular, a stronger pedagogical content knowledge resonated in low mathematics teaching anxiety (Aksu \& Kul, 2019).

From the ongoing, factors that may be responsible for pre-service mathematics teachers' anxiety in teaching mathematics could relate to their knowledge of mathematics content and teaching directly taught, their experiences based on what is observed, and their attitude towards the teaching of mathematics. A break in the synergy among these three factors may put pre-service teachers in an uncomfortable situation that may hinder effective and confident teaching of mathematics content. When pre-service teachers are endowed with strong content and pedagogical mathematical knowledge, they may build a positive attitude towards the teaching of mathematics because their self-confidence would have been boasted. Preservice teachers' knowledge of mathematics content and teaching can however be obtained either through direct instruction by their mathematics educators and/or by observing their mathematics educators and mentors enact mathematics teaching. Corroborating with the latter, Austin intimated that teacher's mathematics based on previous experience. 


\subsection{Conceptual Framework}

Based on the bachelor of education (JHS specialism) mathematics curriculum(IoE, 2018; ITECPD, 2018), preservice teachers' mathematics knowledge of content and teaching, and/or their field experiences are fundamental for assuring effective mathematics teaching. Nonetheless, research postulate that pre-service teachers' desire to conduct effective teaching could be affected by their mathematics teaching anxiety. This analogy led us to form a conceptual framework as presented in Figure 1. In this framework, we hypothesize that pre-service teachers' mathematics achievement and field experience are responsible for effective mathematics teaching. Nevertheless, effective mathematics teaching by pre-service teachers is affected by mathematics teaching anxiety that relates to content knowledge, selfconfidence, the teaching process, and assessment practices.

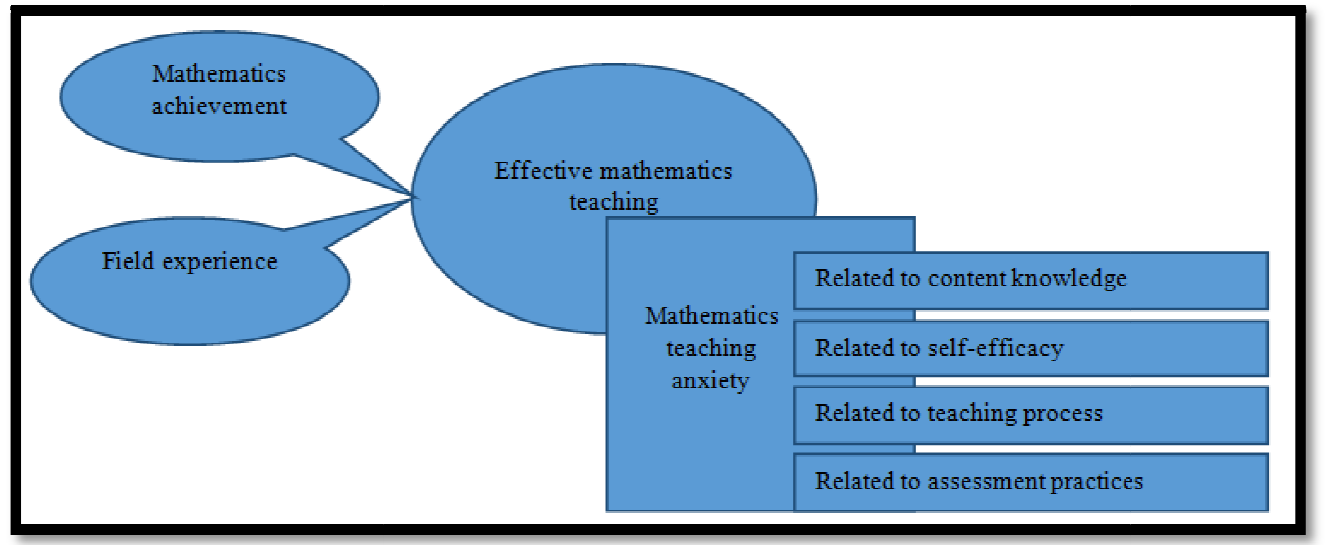

\subsection{Purpose \& Research gap}

Figure 1: Conceptual Framework Relating Mathematics Achievement and Field Experience to Pre-Service Teachers' Mathematics Teaching Anxiety

The year 2000 and beyond has witnessed a plethora of relational studies between mathematics teaching anxiety and pre-service teachers' gender (Ameen et al., 2002; Çenberci, 2019; Akinsola, 2014; Peker et al., 2010)and mathematics anxiety(Haciomeroglu, 2014; Peker \& Ertekin, 2011; Peker, 2009). However, there is a draught in research related to preservice teachers' characteristics such as mathematics achievement and observational field experiences and their anxiety in teaching mathematics. This study, therefore, sought to explore the effect of pre-service teachers' mathematics achievement and field experience on mathematics teaching anxiety among pre-service mathematics teachers in a College of Education in Ghana.

\subsection{Research Questions}

- RQ1: How do major and minor pre-service mathematics teachers differ concerning their anxiety towards the teaching of mathematics?

- RQ2: How well do observational field experience and mathematics achievement predict pre-service teachers' mathematics teaching anxiety?

\section{Method}

\subsection{Participants}

Participants in this study were made up of 119 third year pre-service mathematics teachers from a College of Education in the Ashanti and Bono Ahafo (ASHBA) zone of colleges in Ghana. The 119 participants were all males pursuing a degree programme in basic education (JHS specialism) and were yet to start teaching. The convenience sampling technique (Lammers \& Badia, 2004; Onwuegbuzie \& Collins, 2007) was used to select the pre-service mathematics teachers from among all pre-service mathematics teachers. The convenience sampling was applied because the researchers are teacher educators in that college. At the time of this study, the 119 participants were in two groups of mathematics learning specialism. That is mathematics major pre-service teachers (numbered 67 had completed nine mathematics courses) and mathematics minor pre-service teachers (numbered 52had also completed seven mathematics courses). Curriculum studies in mathematics and Algebraic thinking were two courses that separated the two groups. Besides the difference in the number of mathematics courses completed at the time of this study, both groups had completed three phases of observational field experiences.

\subsection{Design}

To realize the purpose of this study, we embraced a post positivist research orientation. Within this paradigm, the relationship between pre-service teachers' mathematics teaching anxiety levels and their mathematics achievements and field experiences could empirically be gathered and analyzed scientifically using quantitative data(Creswell \& Plano Clark, 2018; Rehman \& Alharthi, 2016). Consequently, a descriptive cross-sectional survey design (McMillan, 2000)was employed. In this design, the mathematics achievement (that is, the aggregation of examination grades in mathematics courses) and the corresponding field experience (that is, the aggregation of field experience course grades) of the 119 preservice mathematics teachers were sourced from the academic affairs unit of the college. Additionally, a survey 
questionnaire was administered to collate the perceptions of the 119 pre-service teachers about their mathematics teaching anxiety.

\subsection{Research Instrument}

The English version of the 23-item Mathematics Teaching Anxiety Scale - MTAS(Hunt \& Sari, 2019) was minimally adapted for this study. The MTAS is a five-point Likert scale that seeks to elicit participants' level of anxiety about the teaching of mathematics. The responses range from a low score of 1 (representing 'Always') to the highest score of 5 (representing 'Never') for which a higher score, means lower anxiety level and vice-versa. The MTAS instrument has been shown in previous studies relating to pre-service teachers' mathematics teaching anxiety to have high internal consistency(Haciomeroglu, 2014; Hunt \& Sari, 2019; Peker \& Ertekin, 2011; Peker, 2006; Sari, 2014). In its multidimensional form, Hunt and Sari (2019) deduced a two-factor structure, Sari (2014) had a three-factor structure, while Peker and Ertekin (2011) and Peker (2006) had a four-factor structure using MTAS. In this study, we sought permission from Mehmet Hayri Sari for the use of the English version of MTAS. Besides its reliability, the English version of MTAS was deemed appropriate based on the language since English is the medium of instruction for training pre-service teachers in Ghana. Modifications we made to the English version of MTAS, included the replacement of the phrase 'pupils/students' with 'learners' to reflect the terms used in the Ghanaian curriculum. Additionally, in consultation with some English Language educators, the tenses used in some of the items were changed into the future tense to reflect the current state of the pre-service teachers who are yet to practice teaching. For example, the original item 'At the end of my math's class, I erase the content on the board so that colleagues can't see' was replaced with 'At the end of my math's class, I will erase the content on the board so that colleagues can't see'. Similarly, the item 'I avoid classroom discussion in case students pose difficult math's questions' was replaced with 'I will avoid classroom discussion in case learners pose difficult math's questions.' Likewise, the item 'I feel nervous when a preservice/trainee teacher observes my math's teaching' was modified to read 'I will feel nervous when an experienced teacher observes my math's teaching'. To maintain the original item meant that this item would not be different from 'I feel uncomfortable when one of my colleagues comes to my classroom during a math's lesson' since the colleagues here were also pre-service teachers. The change was admissible since pre-service teachers tend to be anxious in teaching when a supervisor is present (Capel, 1997).

\section{Analysis}

\subsection{Preliminary Analysis}

The mathematics achievement scores and field experience scores of 111 out of the 119 third year pre-service mathematics teachers were received from the academic affairs unit of the college. The difference was a result of eight preservice mathematics teachers' incomplete examination records. Additionally, two entries were deleted because these preservice mathematics teachers did not complete the mathematics teaching anxiety questionnaire. The remaining 109 entries recorded the least and the highest mathematics teaching anxiety levels of 28 and 100 respectively. Data cleaning resulted in the deletion of 15 more responses identified as outliers. Thus, 94 responses were subsequently used for all analysis. Pre-service mathematics teachers' mean score in the field experience $(M=3.901, S D=.140)$ was higher than their mean mathematics achievement score $(M=2.667, S D=.721)$. A visual examination of the box plot shown that mathematics achievement scores were approximately normally distributed with skewness of -.054 (SE $=-.217$ ) and kurtosis of -1.034 (SE = -2.097) unlike the field experience scores with skewness of -1.209 (SE = -4.855) and kurtosis of721 (SE = 1.462) which was non-normal(Doane\& Seward, 2011).

\subsection{Pre-Service Teachers' Mathematics Teaching Anxiety}

The corresponding 94 responses to the adapted 23 English version of the Mathematics Teaching Anxiety Scale [MTAS_AE] were used to determine the mathematics teaching anxiety levels among pre-service teachers. An exploratory factor analysis was performed to determine the factorability of the adapted 23 English version of the Mathematics Teaching Anxiety Scale [MTAS_AE]. The initial output indicated that the sampling adequacy was satisfied with the KaiserMeyer-Olkin measure of 0.77 , and Bartlett's test of sphericity significant $(\chi 2(253)=944.804, p<.05)$. Additionally, all 23 items of MTAS_AE shared some common variance since the communalities were above 0.3 thus confirming the appropriateness to carry out the factor analysis. After several steps, five items were deleted due to issues relating to failure to meet a minimum factor loading criteria above 0.4 and cross-loadings. The remaining 18 items of MTAS_AE had superior sampling adequacy with the Kaiser-Meyer-Olkin measure of 0.78 , with Bartlett's test of sphericity significant $(\chi 2$ (153) = 615.187, $\mathrm{p}<.05$ ) at minimum communalities of 0.3. Based on Principle Component Analysis and Oblimin with Kaiser Normalization methods, a four-factor structure was produced. This four-factor structure explained 59.1\% of the variance. Upon broad consultations with some teacher educators and following Hunt and Sari (2019), the four factors extracted were accordingly named as (1) Anxiety regarding mathematics teaching processes [TPA]; (2) Anxiety regarding mathematics content knowledge [CKA]; Anxiety related to mathematics self-efficacy [SEA]; and (4) Anxiety regarding assessment practices [APA]. The factor loading matrix for this four-factor structure as well as the internal consistency of each scale measured with Cronbach's alpha is presented in Table 1. 


\begin{tabular}{|c|c|c|c|}
\hline Scale & Items & $\begin{array}{c}\text { Factor } \\
\text { Loadings }\end{array}$ & $\begin{array}{c}\text { Cronbach } \\
\text { Alpha }\end{array}$ \\
\hline \multirow[t]{6}{*}{ CKA } & $\begin{array}{l}\text { I will avoid classroom discussion in case students pose difficult } \\
\text { maths questions. }\end{array}$ & 0.868 & \multirow[t]{6}{*}{$0.850, \mathrm{~N}=5$} \\
\hline & I get uneasy knowing that the next lesson is mathematics. & 0.784 & \\
\hline & $\begin{array}{l}\text { When I am in a maths classes, I will be impatient to see the break } \\
\text { time come quickly. }\end{array}$ & 0.763 & \\
\hline & $\begin{array}{l}\text { I avoid talking about mathematics teaching with other teachers } \\
\text { outside the classroom. }\end{array}$ & 0.650 & \\
\hline & $\begin{array}{l}\text { At the end of my maths class, I will erase the content on the board } \\
\text { so that colleagues can't see. }\end{array}$ & 0.635 & \\
\hline & I am afraid to go beyond the content of/in maths textbooks. & 0.610 & \\
\hline \multirow[t]{4}{*}{ SEA } & $\begin{array}{l}\text { I worry that I won't be able to answer a question whilst teaching } \\
\text { a maths class. }\end{array}$ & 0.818 & \multirow[t]{4}{*}{$0.819, \mathrm{~N}=4$} \\
\hline & $\begin{array}{l}\text { I will feel uncomfortable when one of my colleagues comes to my } \\
\text { classroom during a maths lesson. }\end{array}$ & 0.811 & \\
\hline & $\begin{array}{l}\text { Thinking about how to make use of tools/materials that I don't } \\
\text { know how to use in the maths classroom makes me feel anxious. }\end{array}$ & 0.790 & \\
\hline & $\begin{array}{l}\text { I will feel nervous when an experience teacher observes my } \\
\text { maths teaching. }\end{array}$ & 0.761 & \\
\hline \multirow[t]{5}{*}{ TPA } & $\begin{array}{l}\text { The thought that learners will not meet curriculum/school } \\
\text { targets in maths worries me. }\end{array}$ & 0.822 & \multirow[t]{5}{*}{$0.773, \mathrm{~N}=5$} \\
\hline & $\begin{array}{l}\text { To accommodate different levels of understanding among } \\
\text { learners whilst teaching maths concepts will make me anxious. }\end{array}$ & 0.657 & \\
\hline & $\begin{array}{l}\text { The thought of not being able to motivate learners to learn maths } \\
\text { bothers me. }\end{array}$ & 0.629 & \\
\hline & $\begin{array}{l}\text { Differences in learners' prior knowledge will worry me when I } \\
\text { start to prepare for maths lessons. }\end{array}$ & 0.627 & \\
\hline & $\begin{array}{l}\text { I worry about being able to carry on with the curriculum/school } \\
\text { plan. }\end{array}$ & 0.562 & \\
\hline \multirow[t]{3}{*}{ APA } & $\begin{array}{l}\text { The thought of being unable to effectively use assessment } \\
\text { methods to measure learners' maths abilities in the classroom } \\
\text { makes me feel uneasy. }\end{array}$ & 0.697 & \multirow[t]{3}{*}{$0.554, \mathrm{~N}=3$} \\
\hline & $\begin{array}{l}\text { I worry that learners in my maths class will fail their } \\
\text { assessments. }\end{array}$ & 0.682 & \\
\hline & I worry that learners will answer maths questions incorrectly. & 0.653 & \\
\hline
\end{tabular}

Table 1: Factor Loadings and Cronbach Alpha Based on a Principal Components Analysis with Oblimin Rotation for the Adapted English Version of Mathematics Teaching Anxiety Scale ( $N=94)$

The Alpha levels were moderate. Besides, the correlations among the four scales were generally low (- .102 between CKA and SEA, .518 between CKA and TPA, .313 between CKA and APA, .013 between SEA and TPA, .107 between SEA and APA, and .386 between TPA and APA). Except for the TPA scale, the convergent validity of each scale was satisfied. CKA, SEA, and APA had an average variance extracted [AVE] of at least .5 whereas the AVE for TPA was .4. That notwithstanding, the square root of the AVE foreach of the four factors shown distinctiveness among the scales since the square root of each scale was found to be greater than the correlation between any two dimensions put together (Civelek, 2018; Zainudin, 2012).

Further analysis indicated thatCKA $(M=3.601, S D=1.037)$ had the highest mean score followed by SEA (M=3.332, $\mathrm{SD}=1.139)$, then TPA $(\mathrm{M}=2.783, \mathrm{SD}=.911)$, and APA $(\mathrm{M}=2.667, \mathrm{SD}=.721)$, the overall mathematics teaching anxiety level among the pre-service teachers had a mean score of 3.1424 ( $\mathrm{SD}=.642$ ). The interpretation of the mean scores was based on the reverse interpretation by Deringol (2018)as; 1.00-1.79 'Very high', 1.80-2.59 'High', 2.60-3.39 'Medium/moderate', 3.40-4.19 'Low', 4.20-5.00 'Very low'. From the mean results, pre-service teachers' mathematics teaching anxiety relating to assessment practices and teaching process were high but relatively higher in assessment practices. Furthermore, the pre-service teachers' mathematics teaching anxiety regarding content knowledge and self-efficacy were also moderate but relatively lower in self-efficacy. A Shapiro-Wilk's test (p>.05)(Razali\& Wah, 2011) and a visual examination of the box plot shown that the overall mathematics teaching anxiety score was approximately normally distributed with skewness of $.264(\mathrm{SE}=1.060)$ and kurtosis of .074 (.150)(Doane\& Seward, 2011).

\subsection{The Difference in Pre-Service Mathematics Teachers' Anxiety Related to the Teaching of Mathematics}

From the foregoing, it has been established that the pre-service mathematics teachers had some level of anxiety towards the teaching of mathematics, we sought to find out if the level of anxiety was different between pre-service teachers who minored and those who majored in mathematics. This analysis was done to answer the first research question -How different are major mathematics pre-service teachers' mathematics teaching anxiety from minor mathematics pre-service teachers' mathematics teaching anxiety? A multivariate analysis of variance [MANOVA] was 
conducted to this effect. A chi-square goodness of fit test $(\chi 2(1)=.170, p>.05)$ established equality of sample sizes of minor $(\mathrm{N}=45)$ and major ( $\mathrm{N}=49$ ) mathematics pre-service teachers. Other assumptions such as multivariate outliers, linearity, multicollinearity, multivariate normality and homogeneity of covariance matrices and test of equality of error variance assumptions were not violated (Pallant, 2011).

The descriptive statistics for each model of mathematics teaching anxiety of pre-service mathematics teachers concerning their mathematics specialism is presented in Table 2. As shown in Table 2, the mean levels of pre-service teachers' overall mathematics teaching anxiety relative to their mathematics learning specialism were quite varied. Similarly, there were relatively varied mean differences across the four models of mathematics teaching anxiety. For instance, the mean difference between the two groups of specialisms (major and minor) was much higher in SEA, followed by CKA, then APA and then TPA.

\begin{tabular}{|c|c|c|c|c|c|c|c|}
\hline $\begin{array}{c}\text { Mathematics } \\
\text { Teaching Anxiety }\end{array}$ & \multicolumn{2}{|c|}{ Major (N = 49) } & \multicolumn{2}{c|}{ Minor (N = 45) } & \multicolumn{2}{c|}{ Total (N = 94) } & \multirow{2}{*}{$\begin{array}{c}\text { Absolute mean } \\
\text { difference } \\
\text { (Major - Minor) }\end{array}$} \\
\hline & $\mathrm{M}$ & $\mathrm{SD}$ & $\mathrm{M}$ & $\mathrm{SD}$ & $\mathrm{M}$ & $\mathrm{SD}$ & .420 \\
\hline CKA & 3.802 & .957 & 3.382 & 1.086 & 3.601 & 1.037 & .843 \\
\hline SEA & 2.929 & 1.105 & 3.772 & 1.014 & 3.332 & 1.139 & .113 \\
\hline TPA & 2.837 & .857 & 2.724 & .974 & 2.783 & .911 & .299 \\
\hline APA & 2.714 & .998 & 2.415 & .785 & 2.571 & .910 & \\
\hline
\end{tabular}

Table 2: Means and Standard Deviations for Mathematics Teaching Anxiety by Mathematics Learning Specialism Note. For Each Model of Pre-Service Teachers' Mathematics Teaching Anxiety,

Mathematics Achievement Has $M=2.667$ and $S D=.721$ Whereas Field Experience Has $M=3.901$ And SD = .140

Subsequently, the multivariate test analysis confirmed a statistically significant multivariate difference in mathematics learning specialism concerning the overall mathematics teaching anxiety at Pillai's Trace $=.199, \mathrm{~F}(4,89)=$ $5.521, \mathrm{p}<.001$, partial eta squared $=.199$. The power to detect the difference was about $91 \%$ as presented in Table 3 .

\begin{tabular}{|c|c|c|c|c|c|c|}
\hline $\begin{array}{c}\text { Mathematics Learning } \\
\text { Specialism }\end{array}$ & Multivariate F & $\begin{array}{c}\text { Pillai's } \\
\text { Trace }\end{array}$ & df & $\mathbf{p}$ & $\begin{array}{c}\text { Partial Eta } \\
\text { squared }\end{array}$ & $\begin{array}{c}\text { Observed } \\
\text { power }\end{array}$ \\
\hline Major & 5.521 & .199 & 4 & .001 & .199 & .909 \\
\hline Minor & \multicolumn{3}{|c|}{ Significance at $\mathrm{p}<.05$} \\
\hline \multicolumn{6}{|c|}{}
\end{tabular}

Table 3: Summary of Statistical Difference between Mathematics Learning Specialism

When the results of the pre-service teachers' mathematics teaching anxiety were considered separately as presented in Table 4, only the difference between the mathematics teaching anxiety between majored students and minored students on anxiety regarding self-efficacy attained statistical significance $F(1,92)=14.79$, $p<.001$, based on a Bonferroni adjusted alpha of .0125. The difference was high with a partial eta squared = .14 (Tabachnick \& Fidell, 2013). In confirmation, the mean level of majored mathematics pre-service teachers' mathematics teaching anxiety regarding selfefficacy $(M=2.929$, SD = 1.105) was lower than the mean levels of minored mathematics pre-service teachers' mathematics teaching anxiety regarding self-efficacy $(\mathrm{M}=3.772, \mathrm{SD}=1.014)$. It can be inferred that the mathematics major pre-service teachers had a high mathematics teaching anxiety as compared to the minor pre-service teachers who had moderate mathematics teaching anxiety.

\begin{tabular}{|c|c|c|c|c|c|c|}
\hline Source & $\begin{array}{c}\text { Mathematics } \\
\text { Teaching Anxiety }\end{array}$ & df & F & Sig. & $\begin{array}{c}\text { Partial Eta } \\
\text { Squared }\end{array}$ & $\begin{array}{c}\text { Observed } \\
\text { Power }\end{array}$ \\
\hline \multirow{2}{*}{$\begin{array}{c}\text { Mathematics } \\
\text { learning } \\
\text { specialism }\end{array}$} & CKA & 1 & 3.993 & .049 & .042 & .297 \\
\cline { 2 - 7 } & SEA & 1 & 14.790 & $.000^{*}$ & .138 & .900 \\
\cline { 2 - 7 } & TPA & 1 & .354 & .554 & .004 & .029 \\
\cline { 2 - 7 } & \multicolumn{7}{|c|}{ APA } & 1 & 2.583 & .111 & .027 & .179 \\
\hline
\end{tabular}

Table 4: MANOVA Results for the Four Scales of Mathematics Teaching Anxiety

\subsection{The Effects of Pre-Service Teachers' Field Experience and Mathematics Achievement on Mathematics Teaching Anxiety}

Correlation analysis revealed that CKA, TPA and APA were positively correlated with mathematics achievement. Conversely, SEA was negatively related to mathematics achievement. That notwithstanding, only the relationship between CKA and mathematics achievement reached significance $(r=451, p<.001)$. Also, CKA, SEA, and TPA correlated positively with field experience, whilst APA was negatively associated with field experience. Yet none of these associations was statistically significant.

In predicting the effects of field experience and mathematics achievement on pre-service mathematics teachers' anxiety towards the teaching of mathematics, we were able to answer the second research question - How well do observational field experience and mathematics achievement predict pre-service teachers' mathematics teaching anxiety? 
In separate standard multiple regression analysis, four multiple regression models were developed for CKA, SEA, TPA, and APA. Multiple regression assumptions regarding sample size, multicollinearity, outliers, normality, linearity, homoscedasticity, and independence of residuals(Pallant, 2011) were checked for adherence before we preceded with the analysis. The summary of the ANOVA results for pre-service teachers' mathematics teaching anxiety relating to content knowledge, self-efficacy, teaching process, and assessment practices are presented in Table 5whist the unstandardized and standardized regression coefficients are presented in Table 6. It is instructive to note from Table 2 that in all four models of pre-service teachers' mathematics teaching anxiety, pre-service teachers' mathematics achievement $(\mathrm{M}=2.667, \mathrm{SD}=$ $.721, \mathrm{~N}=94)$ was lower than their field experience $(\mathrm{M}=3.901, \mathrm{SD}=.140, \mathrm{~N}=94)$.

\begin{tabular}{|c|c|c|c|c|c|c|}
\hline \multicolumn{2}{|c|}{ Model } & $S S$ & $d f$ & $M S$ & $F$ & $p$ \\
\hline \multirow[t]{3}{*}{ CKA } & Regression & 20.744 & 2 & 10.372 & 11.899 & .000 \\
\hline & Residual & 79.342 & 91 & .872 & & \\
\hline & Total & 100.068 & 93 & & & \\
\hline \multirow[t]{3}{*}{ SEA } & Regression & 3.741 & 2 & 1.871 & 1.457 & .238 \\
\hline & Residual & 116.807 & 91 & 1.284 & & \\
\hline & Total & 120.549 & 93 & & & \\
\hline \multirow[t]{3}{*}{ TPA } & Regression & 1.072 & 2 & .536 & .640 & .529 \\
\hline & Residual & 76.181 & 91 & .837 & & \\
\hline & Total & 77.253 & 93 & & & \\
\hline \multirow[t]{3}{*}{ APA } & Regression & .098 & 2 & .049 & .058 & .944 \\
\hline & Residual & 76.930 & 91 & .845 & & \\
\hline & Total & 77.027 & 93 & & & \\
\hline
\end{tabular}

Table 5: ANOVA for Multiple Linear Regressions for Mathematics Teaching Anxiety

\begin{tabular}{|c|c|c|c|c|c|c|}
\hline \multicolumn{2}{|c|}{ Model } & $\boldsymbol{B}$ & SE & $\boldsymbol{\beta}$ & $\boldsymbol{t}$ & $\boldsymbol{p}$ \\
\hline \multirow{3}{*}{ CKA } & (Intercept) & .129 & 2.721 & & .047 & .962 \\
\cline { 2 - 7 } & Mathematics achievement & .646 & .134 & .449 & 4.807 & .000 \\
\cline { 2 - 7 } & Field experience & .448 & .694 & .060 & .646 & .520 \\
\hline \multirow{3}{*}{ SEA } & (Intercept) & 1.179 & 3.302 & & .357 & .722 \\
\cline { 2 - 7 } & Mathematics achievement & -.246 & .163 & -.156 & -1.509 & .135 \\
\cline { 2 - 7 } & Field experience & .720 & .843 & .088 & .855 & .395 \\
\hline \multirow{3}{*}{ TPA } & (Intercept) & -.231 & 2.667 & & -.087 & .931 \\
\cline { 2 - 7 } & Mathematics achievement & .019 & .132 & .015 & .144 & .886 \\
\cline { 2 - 7 } & Field experience & .760 & .681 & .116 & 1.116 & .267 \\
\cline { 2 - 7 } & (Intercept) & 2.682 & 2.680 & & 1.001 & .320 \\
\cline { 2 - 7 } & Mathematics achievement & .044 & .132 & .035 & .332 & .741 \\
\cline { 2 - 7 } & Field experience & -.059 & .684 & -.009 & -.086 & .932 \\
\hline
\end{tabular}

Table 6: Coefficients of Multiple Linear Regression for Mathematics Achievement and Field Experience Concerning the Models of Mathematics Teaching Anxiety ( $N=94)$

The results show that the regression model for CKA was statistically significant $\mathrm{F}(2,93)=11.899, p<.001$. The combined effect of mathematics achievement and field experience explained about $20.7 \%\left(\mathrm{R}^{2}=.207\right.$, Adjusted $\left.\mathrm{R}^{2}=.190\right)$ of variance in CKA. In-depth enquiry revealed that both mathematics achievement and field experience contributed positively towards pre-service teachers' mathematics teaching anxiety relating to content knowledge. Nonetheless, mathematics achievement's contribution in predicting the CKA model was significant $(\beta=.449, t=4.807, p<.001)$ to the extent that a unit increase in pre-service teachers' mathematics achievement could lead to about $44.9 \%$ reduction in mathematics teaching anxiety related to content knowledge. The contribution of pre-service teachers' field experience in predicting the CKA model did not statistically reach significance $(\beta=.060, t=.646, p=.520)$.

Unlike the regression model for CKA, the models for SEA $(\mathrm{F}(2,93)=1.457, p=.238)$, TPA $(\mathrm{F}(2,93)=.640, p=$ $.529)$, and APA $(F(2,93)=.058, p=.944)$ did not achieve statistical significance. Invariably, the combined effect of preservice teachers' mathematics achievement and their field experiences could only explain about $3.1 \%\left(\mathrm{R}^{2}=.031\right.$, Adjusted $\left.\mathrm{R}^{2}=.010\right), 1.4 \%\left(\mathrm{R}^{2}=.014\right.$, Adjusted $\left.\mathrm{R}^{2}=-.008\right)$, and $.1 \%\left(\mathrm{R}^{2}=.001\right.$, Adjusted $\left.\mathrm{R}^{2}=-.021\right)$ of the variances in mathematics teaching anxiety relating to self-efficacy, teaching process, and assessment practices respectively. By extension, other factors including chance could be responsible for predicting the SEA, TPA, and APA regression models. The contributions of pre-service teachers' mathematics achievement and their field experiences in predicting the SEA, TPA, and APA models were then observed separately. For the SEA model, both mathematics achievement $(\beta=-.156, t=-1.509, p=.135)$ and field experiences $(\beta=-.088, t=.855, p=.395)$ were not statistically significant in predicting pre-service teachers' mathematics teaching anxiety regarding self-efficacy. Likewise, the TPA model, both mathematics achievement $(\beta=.015, t=.144, p=.886)$ and field experiences $(\beta=.116, t=1.116, p=.267)$ were not statistically significant in predicting pre-service teachers' mathematics teaching anxietyregarding the teaching process. Equally, the APA model, both mathematics achievement $(\beta=.035, t=.332, p=.741)$ and field experiences $(\beta=-.009, t=-.086, p=.932)$ were 
not statistically significant in predicting pre-service teachers' mathematics teaching anxiety regarding assessment practices.

\section{Discussion}

As purposed from the beginning of this study, we sought to explore the effect of pre-service teachers' mathematics achievement and field experience on mathematics teaching anxiety among pre-service mathematics teachers in a College of Education in Ghana. This study has confirmed the prevalence of mathematics teaching anxiety among pre-service mathematics teachers (Deringol, 2018; Levine, 1993; Murat Peker et al., 2010). The anxiety levels of the pre-service teachers towards the teaching of mathematics in this study were generally moderate in contrast to other studies where low anxieties were recorded (Haciomeroglu, 2014).

Besides the aforementioned revelation, we also observed that the mathematics teaching anxiety of the pre-service teachers was related to four domains of teaching (herein referred to as models). Namely, anxiety regarding mathematics teaching processes; anxiety regarding mathematics content knowledge; anxiety related to mathematics self-efficacy; and anxiety regarding assessment practices. Unlike previous researchers, our study elicited the teaching process and assessment practices as separate constructs which hitherto were jointly described as teaching/pedagogical content knowledge (Peker \& Ertekin, 2011; Peker, 2006). Altogether, the English version of the Mathematics Teaching Anxiety Scale (Hunt \& Sari, 2019) was reliable in predicting pre-service teachers' mathematics teaching anxiety.

Inductively, pre-service mathematics teachers in the college have varying levels of apprehension regarding the teaching of mathematics. Particularly, pre-service mathematics teachers have high anxiety regarding assessment and teaching processes but moderate anxiety regarding self-efficacy and content knowledge. Arguably, pre-service teachers have undergone instructions in assessment course. It was expected that pre-service teachers were well equipped with assessment skills to enable them to assess learners without nervousness. Given the state of affairs, the researchers are suspicious about the content of the assessment course, the focus of the assessment course, and perhaps the mode of delivery. It was observed that the content and focus of the assessment course was on general education rather than it being related to mathematics education. The mode of delivery was also virtually enacted using social media platforms. From experience, the use of social media platforms to enact teaching has not been an effective mode of delivery. Especially considering the geographical disposition of pre-service teachers, and the challenges bedeviling online instructions (Kauppi et al., 2020).

Regarding pre-service mathematics teachers' anxiety regarding content knowledge, the researchers noted that the curriculum was well crafted to contain sufficient mathematics content (IoE, 2018). This could explain why the pre-service teachers had moderate teaching anxiety. The observation is synonymous with the conclusions of Aksu and Kul(2019), Baspinar and Peker (2016), and Bostan and Osmanoğlu (2016) regarding mathematics teaching anxiety and content knowledge. We are therefore of the view that the pre-service mathematics teachers might have had adequate content related mathematics knowledge.

The mean levels of pre-service teachers' mathematics teaching anxiety relative to their mathematics learning specialism were not very conspicuouswithcontent knowledge, teaching process, and assessment practices. Regarding selfefficacy, pre-service teachers' mathematics teaching anxiety was more pronounced with the major group as compared to the minor group. By this observation, we are quick to predict that minor pre-service teachers will be more eager to explore more creative teaching methods and thus cause an improvement in their teaching performance (Aksu \& Kul, 2019; Korkmaz, 2004). Ironically, the major group had studied more mathematics courses than the minor group. It was expected that the major group would have had less anxiety than the minor group which never was. It could be inferred that the mathematics achievement of the major group did not contribute to pre-service teachers' overall anxiety towards mathematics teaching. Moreover, students' field experiences might have been a significant factor for ensuring a similar level of overall anxiety among the major and minor groups.

A further observation from our study indicated that an increase in the mathematics achievement of the preservice teachers resulted in a corresponding increase in their mathematics teaching anxiety regarding content knowledge. Perhaps, the more their abilities to score good grades in mathematics-related courses, the greater the chance that they become anxious about teaching mathematics. This observation contradicts the opinion that content knowledge is inversely related to mathematics teaching anxiety (Baspinar \& Peker, 2016). The suspension of the researchers is that the content of the mathematics courses the pre-service teachers are learning in the college could be at variance with the content of the mathematics the pre-service teachers will be teaching. This confirms the assertion that teachers are more comfortable teaching what they know. In this regard, the pre-service teachers will better understand the mathematics in the learners' curriculum, thereby being able to plan and carry out effective instruction (Ball et al., 2008).

Finally, we observed from the content knowledge related anxiety of the pre-service teachers' that, mathematics achievement was a driving force rather than field experience. Since content knowledge associates inversely with mathematics teaching anxiety(Baspinar \& Peker, 2016), it suffices to admit that the higher the achievement level which is based on the content knowledge, the lower the anxiety towards the teaching of mathematics.

\section{Summary, Conclusion \& Recommendation}

Our study has revealed that pre-service mathematics teachers are anxious to teach mathematics. Though moderate, there should not be high apprehension among teacher educators and stakeholders of the college. This is because, anxiety associated with teaching is circumstantial which can be resolved (Ameen et al., 2002). While we suspect the preparedness of pre-service mathematics teachers to enact effective teaching of mathematics, we are inclined to 
propose that the use of manipulatives, adoption of creative teaching strategies, and provision of lesson plans for specific mathematics topics may help reduce the levels of pre-service teachers' anxiety in teaching mathematics.

Our study was limited to a single college of education in Ghana and the result may not necessarily resonate with happenings in other colleges of education. We recommend that a larger sample might help resolve this limitation.

\section{Acknowledgement}

The authors in this study are grateful to the pre-service mathematics teachers for taking part in this study. The researchers are also grateful to all anonymous reviewers for the valuable suggestions.

\section{Declaration of Conflict of Interest}

We, the researchers declare that we have no competing interest in this study.

\section{References}

i. Akinsola, K. M. (2014). Assessing pre-service teachers teaching anxiety. American Journal of Educational Research, 2(12A), 41-44. https://doi.org/10.12691/education-2-12A-7

ii. Aksu, Z., \&Kul, Ü. (2019). The mediating role of mathematics teaching efficacy on the relationships between pedagogical content knowledge and mathematics teaching anxiety. SAGE Open, 9(3), 215824401987104. https://doi.org/10.1177/2158244019871049

iii. Alkan, V., Coşguner, T., \&Fidan, Y. (2019). Mathematics teaching anxiety scale: Construction, reliability and validity. International Journal of Assessment Tools in Education, 6(3), 506-521. https://doi.org/https://dx.doi.org/10.21449/ijate.625423

iv. Ameen, E. C., Guffey, D. M., \& Jackson, C. (2002). Evidence of Teaching Anxiety Among Accounting Educators. Journal of Education for Business, 78(1), 16-22. https://doi.org/10.1080/08832320209599692

v. Ball, L. D., Thames, M. H., \& Phelps, G. (2008). Content knowledge for teaching. What makes it special? Journal of Teacher Education, 59(5), 389-407. https://doi.org/10.1177/0022487108324554

vi. Baspinar, K., \&Peker, M. (2016). The Relationship between Pre-Service Primary School Teachers' Mathematics Teaching Anxiety and Their Beliefs about Teaching and Learning Mathematics. KuramsalEğitimbilim, 9(1), 1-14. https://doi.org/10.5578/keg.10628

vii. Bostan, M. I., \&Osmanoğlu, A. (2016). Pedagojik Alan Bilgisi [PCK]. In S. A. Bingölbali. \& İ. Ö. Zembat (Eds.), MatematikEğitimindeTeoriler [Theories in Mathematics Education] (Eds., pp. 677-699). Pegem A.

viii. Brown, A., Westenskow, A., \& Moyer-Packenham, P. (2012). Teaching Education Teaching anxieties revealed: pre-service elementary teachers' reflections on their mathematics teaching experiences. Taylor \& Francis, 23(4), 365-385. https://doi.org/10.1080/10476210.2012.727794

ix. Capel, S. A. (1997). Changes in students' anxieties and concern after their first and second teaching practices. Educational Researchers, 39(2), 211-228.

x. Cenberci, S. (2019). The examination of prospective mathematics teachers' mathematics teaching anxiety levels. Journal of Theoretical Educational Science, 12(4), 1193-1208. https://doi.org/10.30831/akukeg.455708

xi. Creswell, J. W., \& Plano Clark, V. L. (2018). Designing and conducting mixed methods research. In Thousand Oaks, California: SAGE Publications Inc. (3rd ed.). SAGE Publications Inc.

xii. Deringol, Y. (2018). Mathematics teaching anxiety of classroom teachers. In I. Koleva, A. H. Basal, M. Tufan, \& E. Atasoy (Eds.), Educational Sciences Research in the Globalizing World. St. KlimentOhridski University Press.

xiii. Doane, D. P., \& Seward, L. E. (2011). Measuring skewness: a forgotten statistic? Journal of Statistics Education, 19(2), 1-18. https://doi.org/10.1080/10691898.2011.11889611

xiv. Ertekin, E. (2010). Correlations between the mathematics teaching anxieties of pre-service primary education mathematics teachers and their beliefs about mathematics. Educational Research and Reviews, 5(8), 446-454.

xv. Gardner, L. E., \& Leak, G. K. (1994). Characteristics and Correlates of Teaching Anxiety among College Psychology Teachers. Teaching of Psychology, 21(1), 28-32. https://doi.org/10.1207/s15328023top2101_5

xvi. Haciomeroglu, G. (2014). Elementary pre-service teachers' mathematics anxiety and mathematics teaching anxiety. In International Journal for Mathematics Teaching \& Learning. http://www.cimt.org.uk/journal/haciomeroglu.pdf

xvii. Hacıömeroğlu, G. (2013). Mathematics anxiety and mathematics beliefs: What is the relationship in elementary pre-service teachers? IUMPST, 5, 1-9.

xviii. Hunt, E. T., \& Sari, H. M. (2019). An English Version of the Mathematics Teaching Anxiety Scale. International Journal of Assessment Tools in Education, 6(3), 436-443. https://doi.org/https://dx.doi.org/10.21449/ijate.615640

xix. Institute for teacher education and continuing professional development, ITECPD. (2018). Four-year bachelor of education degree: Eight-semester initial teacher education curriculum (Junior high school). University of Education.

xx. Institute of Education, IoE. (2018). Four-year bachelor of education for colleges of education. College of Education Studies, School of Educational Development and Outreach.

xxi. Kauppi, S., Muukkonen, H., Suorsa, T., \&Takala, M. (2020). I still miss human contact, but this is more flexibleParadoxes in virtual learning interaction and multidisciplinary collaboration. British Journal of Educational Technology. https://doi.org/10.1111/bjet.12929 
xxii. Korkmaz, I. (2004). SosyalÖğrenmeKuramı [Social learning theory]. In B. Yesilyaprak (Ed.), EğitimPsikolojisi [Psychology of education] (pp. 197-222). Pegem A.

xxiii. Lammers, W. J., \&Badia, P. (2004). Fundamentals of behavioral research. Recording for the Blind \& Dyslexic.

xxiv. Levine, G. (1993). Prior mathematics history, anticipated mathematics teaching style, and anxiety for teaching mathematics among pre-service elementary school teachers. 15th Annual Meeting of the 'International Group for the Psychology of Mathematics Education, North American Chapter.

xxv. McMillan, J. H. (2000). Educational research: Fundamentals for the consumer (3rd Ed). Addison Wesley Longman.

xxvi. Mohd Razali, N., \& Bee Wah, Y. (2011). Power comparisons of Shapiro-Wilk, Kolmogorov-Smirnov, Lilliefors and Anderson-Darling tests. In Journal of Statistical Modeling and Analytics (Vol. 2, Issue 1). https://www.researchgate.net/profile/Bee_Yap/publication/267205556_Power_Comparisons_of_ShapiroWilk_Kolmogorov-Smirnov_Lilliefors_and_Anderson-Darling_Tests/links/5477245b0cf29afed61446e1/PowerComparisons-of-Shapiro-Wilk-Kolmogorov-Smirnov-Lilliefors-an

xxvii. Onwuegbuzie, A. J., \& Collins, K. M. T. (2007). A Typology of Mixed Methods Sampling Designs in Social Science Research. The Qualitative Report, 12(2), 281-316. https://files.eric.ed.gov/fulltext/EJ800183.pdf

xxviii. Pallant, J. (2011). SPSS survival manual 4th ed. In Allen \& Unwin.

xxix. Peker, M. (2015). The relationship between mathematics teaching anxiety and self-efficacy beliefs toward mathematics teaching. International Conference on Social Sciences and Education Research.

xxx. Peker, M., \&Ertekin, E. (2011). The relationship between mathematics teaching anxiety and mathematics anxiety. The New Educational Review, 23(1), 213-226. https://www.researchgate.net/publication/256482283

xxxi. Peker, M, \&Ertekin, E. (2011). The relationship between mathematics teaching anxiety and mathematics anxiety. The New Educational Review, 23(1), 213-226.

xxxii. Peker, Murat. (2006). MATEMATTK ÖĞRETMEYE YÖNELLK KAYGI ÖLÇEĞĞNNN GELLŞTTRRLMESS. EğitimBilimlerive Uygulama,9(0), 73-92. https://toad.halileksi.net/sites/default/files/pdf/matematikogretmeye-yonelik-kaygi-olcegi-toad.pdf

xxxiii. Peker, Murat. (2009). Pre-service teachers' teaching anxiety about mathematics and their learning styles. EURASIA Journal of Mathematics, Science and Technology Education, 5(4), 335-345. https://doi.org/10.12973/ejmste/75284

xxxiv. Peker, Murat, Halat, E., \&Mirasyedioğlu, Ş. (2010). Gender related differences in mathematics teaching anxiety. The Mathematics Educator, 12(2), 125-140.

xxxv. Rehman, A. A., \&Alharthi, K. (2016). An introduction to research paradigms. International Journal of Educational Investigations, 3(8), 51-59. www.ijeionline.com

xxxvi. Sari, M. H. (2014). Developing a mathematics teaching anxiety scale for classroom teachers. Elementary Education Online, 13(4), 1296-1310. https://doi.org/10.17051/io.2014.11721

xxxvii. Tabachnick, B. G., \&Fidell, l. S. (2013). Using multivariate statistics (6th ed.). Pearson. https://scholar.google.com/scholar?hl=en\&as_sdt=0\%2C5\&q=Tabachnick\%2C+B.+G.+\%26+Fidell\%2C+l.+S.+\% $282012 \% 29+$ Using+multivariate+statistics.\&btnG=

xxxviii. URAL, A. (2015). The Effect of Mathematics Self-Efficacy on Anxiety of Teaching Mathematics. KuramsalEğitimbilim, 2015(2), 173-184. https://doi.org/10.5578/keg.9075 